\title{
Biochemical and economic studies on two hybrids of silkworm (Bombyx mori L.)
}

\author{
A. H. El saffany ", M. M. Abdel- Ghaffar, M. K. El-Ansari and M. K. Hamza
}

Plant Protection Department, Faculty of Agriculture, AL-Azhar University, Nasr City, Cairo, Egypt

*Corresponding author E-mail: elsaffany7@azhar.edu.eg (A. El saffany).

\begin{abstract}
Silkworm is a typical monophagous insect and mulberry (Morus spp.) leaf is its sole feed. The current investigation aims to compare biochemical and economic characteristics of two hybrids of silkworms ( $B$. mori. L.). Two hybrids of Bombyx mori, (L.) (H1xKKxG2xV2) and (Giza B) silkworm larvae were fed on mulberry leaves Morus indica var kanava-2 planted in the experimental farm during the spring season for biochemical and economic studies. Mulberry leaves were offered four times per day. The imported hybrid (H1xKKxG2xV2) showed higher and consistent growth rates than the native hybrid (Giza B) for all the developmental stages. It can be concluded that the selection of strong hybrids from silkworm and feeding on a good variety of Indian cultivar Morus alba var. kanava-2 imported from Indian improves the growth value of biological and economic parameters.
\end{abstract}

Keywords: Bombyx Mori L.; Biochemical character; Silkworm.

\section{INTRODUCTION}

Bombyx mori L. commonly known as mulberry silkworm reared on mulberry plant. It is a commercial exploited variety used on large scale production of silk Mahmoud (2013). One of the most important characteristics of the silkworm B. mori $\mathrm{L}$. is its ability to switch plant proteins from feeding material to silk proteins. Silkworm is a typical monophagous insect and mulberry (Morus spp.) leaf is its sole food. Man has immensely benefited from the silk produced by silkworms and subsequently researchers have always been trying to unveil the factors that can be manipulated to the benefit of the silkworm rearers (Nair and Kumar 2004).

Mulberry leaf exclusively assures the growth and development of the silkworm larvae, being considered a complete value nutrient, so that the knowledge of its nutritional status is of great interest. The nutritional status of different mulberry varieties is ascertained by its biochemical constituents. Mulberry is rich source of protein, carbohydrate, carotenoids, lipids, ascorbic acid, anthocyanins etc. Physiological activity of the insect depends on haemolymph that is the only extra cellular fluid having diverse functions such as immunity, and as the reservoir for the products which are required for survival (Sowri and Sarangi, 2002). Also protein has an interesting biochemical role in the development, morphogenesis and almost in all intermediary metabolic pathways of insects and since they are the key organic constituent, their role in the compensatory mechanism of silkworm is vital (Hiremath et al., 2006; Ramakrishna and Jayaprakash, 2007).

Sericulture is one of the most important industries in several countries, however, in Egypt it is not well developed due to several factors; one of these is lack of good hybrid with high productivity. Therefore, it is necessary to evaluate imported hybrids to determine their suitability to our climatic condition. The recent increase of domestic and international markets for silk production combined to the deep-rooted national traditions as well as the favorable climatic condition gives a push for developing the sericulture in Egypt as reported by Souad and Azza (2008).

Hence the aim of the current investigation is to evaluate biochemical and economic characteristics on two hybrids of silkworms, $B$. mori L..

\section{MATERIALS AND METHODS}

\section{Silkworm eggs resources}

We used eggs of the two silkworm (B. mori L.) hybrids (H1xKKxG2xV2), produced by the Sericulture and Agriculture Experiment Station, Vratza, Bulgaria and Native Hybrid (Giza B).

\section{Silkworm rearing technique}

Silkworm eggs of the two hybrids were obtained from the Sericulture Research Department (SRD) of the Plant Protection Research Institute (PPRI). Eggs were incubated in an incubator adjusted at $25 \pm 2^{\circ} \mathrm{C}$ and $75 \pm 5 \%$ R.H. Hatched larvae were transferred from the egg cards to the rearing 
trays. Removal of fecal matter and diseased larvae as well as bed cleaning was done at regular intervals. Larvae were divided into two groups. Each group was fed four times a day on the fresh mulberry of Morus indica var kanava- 2 variety. The young larvae $\left(1^{\text {st }} \pm 3^{\text {rd }}\right.$ instars) were reared at $27 \pm 2^{\circ} \mathrm{C}, 85 \pm 5 \%$ (R.H.) and the late age larvae ( $4^{\text {th }}$ and $5^{\text {th }}$ instars) were maintained at $24 \pm 2{ }^{\circ} \mathrm{C}$ with R.H. of 70 $\pm 5 \%$. Each hybrid was reared in three replicates. At the beginning of $4^{\text {th }}$ instar, 300 larvae were counted from each hybrid and retained for further studies. Rearing was carried out under hygienic conditions according to Krishnaswami (1978). Larval weights of fifth instars were recorded at $7^{\text {th }}$ day of $5^{\text {th }}$ larval instar while larval haemolymph samples were collected at $6^{\text {th }}$ day for biochemical analysis. The spinning larvae were collected manually and mounted in plastic collapsible montages. Observations on fecundity, fertility, hatchability percentage, pupal weight, pupation ratio, cocooning percentage, single cocoon and single shell weights, single cocoon shell ratio were recorded.

\section{Bioassay assessment of silkworm.}

\section{Total proteins}

Total proteins were determined by the method of Bradford (1976). The results were expressed as $(\mathrm{mg} / \mathrm{mL})$

\section{Free amino acids}

Total amino acids were calorimetrically estimated by ninhydrin reagent according to the method described by Lee and Takabashi
(1966). Amino acids were expressed as mg D, L- alanine /mL.

\section{Alkaline phosphatase (U/L)}

Acid and alkaline phosphatases were determined according to the method described by Powell and Smith (1954). The enzyme activity is expressed by unit $(\mathrm{U} / \mathrm{L})$.

\section{Transaminases (GOT and GPT)}

Glutamic pyruvic transaminase (GPT) and glutamic oxaloacetic transaminase (GOT) were determined calorimetrically according to the method of Reitman and Franke (1957). The enzyme activity is expressed as $\mathrm{U} / \mathrm{g}$ body weight.

\section{Statistical analysis}

Data were subjected to t-test by using Costat program (1988) at probability level of $\mathrm{P}$ $=0.05$.

\section{RESULTS AND DISCUSSION}

\section{Biological aspects.}

The mean values of biological parameters of the imported and native hybrids were tabulated in Table (1). Larval duration was non - significantly shorter in imported hybrid compared with (26.5 days) and native hybrid (28.2 days). However, the mean weight of the fourth instar larvae was higher significantly $(1.387 \mathrm{~g})$ in imported hybrid compared with native hybrid $(1.109 \mathrm{~g})$. The mean weight of fifth instar larvae (immature and mature) of imported hybrids increased significantly (0.596 and 2.135g) compared to native hybrid (0.477 and $1.515 \mathrm{~g})$ respectively.

Table 1. Some biological aspects of two silkworm (B. mori L.) hybrids.

\begin{tabular}{|c|c|c|c|c|}
\hline \multirow[b]{3}{*}{ Silkworm hybrids } & \multirow{3}{*}{$\begin{array}{l}\text { Larval } \\
\text { duration } \\
\text { (days) }\end{array}$} & \multicolumn{3}{|c|}{ Mean larvae weight(g) } \\
\hline & & \multirow[b]{2}{*}{$\begin{array}{c}\text { Beginning of } 4^{\text {th }} \\
\text { instar } \\
(10 \text { larvae } / w t)\end{array}$} & \multicolumn{2}{|c|}{$5^{\text {th }}$ instar larvae } \\
\hline & & & $\begin{array}{l}\text { Immature } \\
\text { beginning } \\
\text { ( larva / wt ) }\end{array}$ & $\begin{array}{c}\text { Mature } \\
\text { end } \\
\text { ( larva / wt ) }\end{array}$ \\
\hline $\begin{array}{l}\text { Imported hybrids } \\
(\mathrm{H} 1 \times K K \times \mathrm{G} 2 \times \mathrm{V} 2)\end{array}$ & 26.5 & 1.387 & 0.596 & 2.135 \\
\hline $\begin{array}{l}\text { Native hybrid } \\
\text { (Giza B) }\end{array}$ & 28.2 & 1.109 & 0.477 & 1.515 \\
\hline t value & 2.96 & 10.801 & 134.55 & 14.491 \\
\hline$P(t=0)$ & $0.994^{\mathrm{ns}}$ & $0.008^{* *}$ & $0.001^{* * *}$ & $0.004^{* * *}$ \\
\hline
\end{tabular}

\section{Fecundity, Fertility, Hatchability\%, Pupal} weight and Pupation ratio

As represented in Table (2) mean number of deposited eggs / female as reproductive index was varied between treatments. The fecundity was 330 eggs / female, with fertility
322.0 eggs / female, in imported hybrid and 305, eggs / female, and 287.67 egg / female for native hybrid with no significance in fecundity and fertility, respectively, egg hatching percentage/ laid by female moth resulted from larvae of imported and native 
hybrids were $97.76 \%$ and $94.31 \%$, respectively. Pupal weight for imported and native hybrids recorded $0.716 \& 0.612 \mathrm{~g}$ and $0.845 \mathrm{~g} \& 0.740 \mathrm{~g}$ for male and female, respectively, with high significant differences.
Pupation ratio for both sexes recorded were 95.87, $95.53 \%$ and $96.63,96.07 \%$ for male and female of imported and native hybrids, respectively.

Table 2. Some biological aspects of two silkworm (B. mori L.) hybrids.

\begin{tabular}{cccccccc}
\hline Silkworm hybrids & $\begin{array}{c}\text { Fecundity } \\
\text { No) }\end{array}$ & $\begin{array}{c}\text { Fertility } \\
(\mathrm{No})\end{array}$ & $\begin{array}{c}\text { Hatchability } \\
(\%)\end{array}$ & \multicolumn{2}{c}{ Pupal weight $(\mathrm{g})$} & \multicolumn{2}{c}{ Pupation ratio (\%) } \\
\hline $\begin{array}{c}\text { Imported hybrids } \\
\text { (H1xKKxG2xV2) }\end{array}$ & 330.0 & 322.6 & 97.76 & 0.716 & 0.845 & 95.87 & 96.63 \\
$\begin{array}{c}\text { Native hybrid(Giza } \\
\text { B) }\end{array}$ & 305.0 & 287.67 & 94.31 & 0.612 & 0.740 & 95.53 & 96.07 \\
$\mathrm{t}$ value & 1.013 & 1.587 & 5.175 & 4.421 & 3.725 & 10.00 & 1.331 \\
$\mathrm{P}(\mathrm{t}=0)$ & $0.417^{\mathrm{ns}}$ & $0.253^{\mathrm{ns}}$ & $0.035^{*}$ & $0.001^{* *}$ & $0.004^{* *}$ & $0.009^{* *}$ & $0.314^{\mathrm{ns}}$ \\
\hline
\end{tabular}

These finding are in accordance with Megalla et al. (1997) they reported that, significant positive variations were estimated among the different imported hybrids in biological and technological values compared with the Korean hybrid annually reared in Egypt.

These results are supported by those of Souad and Ghazy (2005) they reported that Thailand hybrids were good for breeding programs in Egypt, and they were superior for biological and cocoon characters.

Values of these results are consistent with Souad and Azza (2008) they found that the imported hybrids showed the best performance in most biological characters compared with the Egyptian hybrid. At the same trend, Prakash (1986) observed that estimation of different biological characters especially fecundity, fertility, hatchability and cocooning \% characters were linked with disease resistance and healthiness.

\section{Economic characters.}

Cocoon and cocoon crop characters linked to the economic aspects were determined and registered in Table (3). Data show that the imported hybrid was better than the local hybrid in economic characteristics, there was highly significant of fresh cocoon weights $0.883,1.020 \mathrm{~g}$ imported variety and 0.750 , $0.884 \mathrm{~g}$ for native variety male and female, respectively. The same trend for cocoon shell weights $0.172,0.172 \mathrm{~g}$ and $0.140,0.143 \mathrm{~g}$ for imported and native variety, respectively. The other tested parameters cocoon shell ratio with no significant in imported and native varieties $19.48,16.80$ and $18.54,16.19 \%$ for male and female, respectively.

Table 3. Some economical characters of two hybrids of silkworm (B. mori L.).

\begin{tabular}{ccccccc}
\hline \multirow{2}{*}{ Silkworm hybrids } & \multicolumn{2}{c}{ Fresh Cocoon Weight $(\mathrm{g})$} & \multicolumn{2}{c}{ Cocoon Shell Weight $(\mathrm{g})$} & \multicolumn{2}{c}{ Cocoon Shell Ratio (\%) } \\
\cline { 2 - 7 } & Male & Female & Male & Female & Male & Female \\
\hline $\begin{array}{c}\text { Imported hybrids } \\
\text { (H1xKKxG2xV2) }\end{array}$ & 0.883 & 1.020 & 0.172 & 0.172 & 19.48 & 16.86 \\
Native hybrid(Giza & 0.750 & 0.884 & 0.140 & 0.143 & 18.54 & 16.19 \\
B) & 4.469 & 3.683 & 2.787 & 3.747 & 0.847 & 0.993 \\
t value & $0.001^{* *}$ & $0.005^{* *}$ & $0.021^{*}$ & $0.004^{* *}$ & $0.418^{\text {ns }}$ & $0.346^{\text {ns }}$ \\
P(t=0) & & & & &
\end{tabular}

Rehab et al. (2017) recommended that superior hybrids of silkworm firstly need to evaluate these hybrids before their release into the field. Cocoon and cocoon crop characters linked to the economic aspects were significantly the highest cocoon shell ratio and randitta comparing to Thai 2 and Egyptian hybrid. These results are supported by those of Souad and Ghazy (2005) who reported that, Thailand hybrids were good for breeding programs in Egypt, and they were superior for biological and cocoon characters. Also, pupa weights, pupation $\%$ and cocooning percentage exhibited the highest values with imported hybrids (H1xKKxG2xV2) compared with the native hybrid. Imported hybrids showed good performance and remarkable superiority over the Egyptian hybrid therefore, it may be recommended to use these 
imported hybrids in the breeding programs for the production of superior local hybrids.

Table (4) show that Silk productivity \% (Cg / days) for imported and native hybrids were highly significant $(1.71,0.13 \& 1.72,0.12$ for male and female, respectively) further, cocooning percentage were $97.53,97.30 \%$; and 97.30, 93.23 for male and female, respectively with significant differences. These results are supported by those of Souad and Ghazy (2005), who reported that, Thailand hybrids were good for breeding programs in Egypt, and they were superior for biological and cocoon characters.

Table 4. Some economic parameters of two hybrids of B. mori L.

\begin{tabular}{ccccc}
\hline & \multicolumn{2}{c}{ Silk prod.\% (Cg./days) } & \multicolumn{2}{c}{ Cocooning \% } \\
\cline { 2 - 5 } Silkworm hybrids & Male & Female & Male & Female \\
\hline Imported hybrids & 1.71 & 1.72 & 97.53 & 97.30 \\
(H1xKKxG2xV2) & & & & \\
Native hybrid(Giza B) & 0.13 & 0.12 & 97.30 & 93.23 \\
$\mathrm{t}$ value & 29.310 & 31.611 & 1.079 & 1.00 \\
$\mathrm{P}(\mathrm{t}=0)$ & $0.00^{* * *}$ & $0.00^{* * *}$ & $0.393^{\mathrm{ns}}$ & $0.422^{\mathrm{ns}}$ \\
\hline
\end{tabular}

\section{Biochemical analysis:}

Results in Table (5) revealed that total protein, free amino acid, alkaline phosphatase, GOT, and GPT, was different two hybrids in $B$. mori haemolymph of $5^{\text {th }}$ instar larvae fed on Morus alba var kanava-2 were no significant in total protein 109.4, $107.4 \mathrm{mg} / \mathrm{mL}$ for imported and native hybrid. While recorded was highly significant in free amino acid $687.7,430.2 \mathrm{mg}$ $\mathrm{D}$, L-alanine $/ \mathrm{mL}$ for imported and native hybrid. Alkaline phosphatases were 21.4, 11.4 $\mathrm{U} / \mathrm{L}$ for imported and native hybrid. With highly significant for GOT and GPT were
254.4, 230 and 150.7, 117.7 U/L) for imported and native hybrid; respectively. The difference was non-significant, for GOT, and GPT.

These results are in agreement with Rajannan et al. (1994) and Rehab et al. (2017) thy found that total protein concentration differed according to races. Both Thai hybrids 1 and 2 showed good performance and remarkable superiority over the Egyptian hybrid therefore, it may be recommended to use these imported hybrids in the breeding programs for the production of superior local hybrids.

Table 5. Some biochemical analysis of two hybrids of B. mori, L.

\begin{tabular}{|c|c|c|c|c|c|}
\hline Parameters & $\begin{array}{l}\text { Total protein } \\
(\mathrm{mg} / \mathrm{mL})\end{array}$ & $\begin{array}{l}\text { Free amino } \\
\text { acid }(\mathrm{mg} \text { D,L- } \\
\text { alanine } / \mathrm{mL})\end{array}$ & $\begin{array}{c}\text { Alkaline } \\
\text { phosphatase } \\
(\mathrm{U} / \mathrm{L}))\end{array}$ & $\begin{array}{l}\text { GOT } \\
(\mathrm{U} / \mathrm{L})\end{array}$ & $\begin{array}{l}\text { GPT } \\
(\mathrm{U} / \mathrm{L})\end{array}$ \\
\hline $\begin{array}{c}\text { Imported hybrids } \\
(\mathrm{H} 1 \times K K \times G 2 \times V 2)\end{array}$ & 109.4 & 687.7 & 21.4 & 254.4 & 150.7 \\
\hline Native hybrid(Giza B) & 107.4 & 430.2 & 11.4 & 230 & 117.7 \\
\hline $\mathrm{t}$ value & 0.405 & 13.562 & 7.8 & 2.444 & 2.494 \\
\hline$P(t=0)$ & $0.724^{\mathrm{ns}}$ & $0.005^{* *}$ & $0.000^{* *}$ & $0.134^{\mathrm{ns}}$ & $0.130^{\mathrm{ns}}$ \\
\hline
\end{tabular}

\section{REFERENCES}

Bradford, M.M., I976. A rapid and sensitive method for the quantitation of microgram quantities of proteins utilizing the principle of protein-dye binding. Anal. Biochem., 72, 248-254.

Costat software, 1988. Microcomputer program analysis, CoHort software, Berkely, CA, USA.

Hiremath, S.S., Srikar, L.N., Narayanaswamy, T.K., Poddar, U.S., Shankar, M.A., 2006. Biochemical constituents of silkworm, Bombyx mori, L. as influenced by grow through organic based nutrient management. Sericologia, 46(3), 351-355.

Krishnaswami, S., 1978. New technology of silkworm rearing. Central Sericulture Researches and Training Inst., Mysore Bull., 2, 1-10.

Lee, Y.P., Takabashi, T., 1966. An improved colorimetric determination of amino acids with the use of ninhydrin. Anal. Biochem., 14, 71-77. 
Mahmoud, M.M., 2013. Effect of various kinds of dietary proteins in semi - artificial diets on the mulberry silkworm Bombyx mori, L. Egypt. Acad. J. Bio. Sci., 6 (1), 21-26.

Megalla, A.H., Souad, M.M., Zannon, A.A. 1997. Performance of different imported silkworm hybrids of Bombyx mori, L. under the Egyptian conditions. Proc. 1st. Int. Conf. silk "ICSAI", 72-77.

Nair, J.S., Kumar, S.N., 2004. Artificial diet for the silkworm, Bombyx mori, L. A retrospection through the decades. Ind. J. Sericul., 43 (1), 1- 17.

Prakash, K.R., 1986. A Study on Adoption of Improved Sericultural Practices and Labour Utilization among Big, Small and Tenant Farmers of Ramanagara Taluk, Bangalore District. MSc. Thesis, University of Agricultural Science, Bangalare, India.

Rajannan, K.L., Pattarju, H.P., Manjula, A.C.A., Yadav, P.R., 1994. Biochemical differences among some selected lines of two different voltine races of Bombyx mori, L. J. Entomol. Res., 18 (1), 53-60.

Ramakrishna, S., Jayaprakash ,2007. Shifts in protein metabolism in haemolymph and fat body of the silkworm, Bombyx mori, L. in response to fuccid toxicity. Int. J. Entomol., 15 (1), 59-68.

Rehab, H.T., Eman, M.H., Marwa, N.M., 2017. Assessment of different imported hybrids of mulberry silkworm, Bombyx mori, L. in Egypt. Egypt. Acad. J. Biol. Sci., 10 (7), 99-105.

Reitman, S., Franke, S., 1957. Colourimetric method for aspartate and alanine transaminases. Am. J. Clin. Pathol., 28, 55-60.

Souad, M.M., Azza, T.A., 2008. Biometric and biochemical studies on different hybrids of the mulberry silkworm, Bombyx mori, L. Bull. Entomol. Soc. Egypt, 85: 73-83.

Souad, M.M., Ghazy, M.M.U., 2005. Performance of two hybrids of silkworm, Bombyx mori, L. in different locations. Egypt. J. Agric. Res., 83 (3), 1039-1041.

Sowri, D.M., Sarangi, S.K., 2002. Changes in protein and reducing sugar content of the haemolymph during $\mathrm{v}$ instar development of Bombyx mori, L. Bull. Ini. Acad. Seric., 6 (2), 103-106.

Tatchell, R.J., Araman, S.F., Boctor, F.N., 1972. Biochemical and physiological studies of certain Ticks (Ixodoidea). Z. Parsitenk., 39, 345-350. 


\section{دراسات بيوكيميائية واقتصادية لهجينين من دودة الحرير التوتية \\ أحمد حسن الصفاني "، محمد عبد الففار محمود، محمد كمال الدين الانصاري، محمد كامل عبد الصمد حمزة}

قسم وقاية النبات شعبة الحشرات الاقتصادية، كلية الزراعة بالقاهرة، جامعة الأزهر ، مدينة نصر، القاهرة، مصر

elsaffany7@azhar.edu.eg البريد الإليكتروني للباحث الرئيسي: *

الملخص العربي

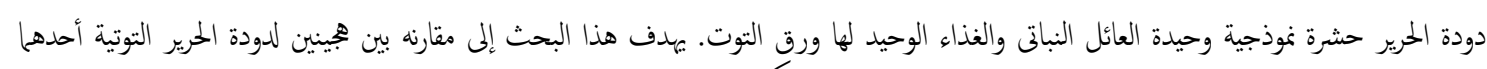

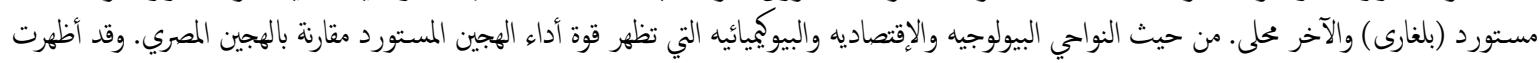



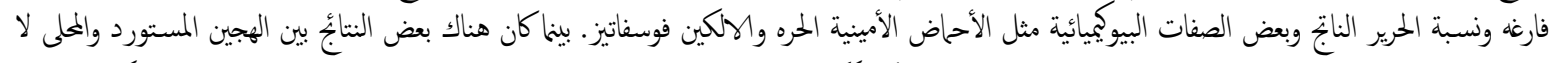



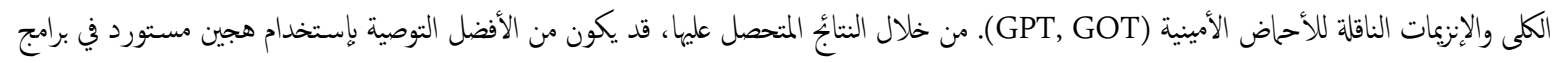


الكلمات المفتاحية: دودة الحرير التوتية، الصفات البيولوجية، الدراسات الإقتصادية. 